\title{
Weed Management with Herbicides ApPlied in PRe and Postemergence on Castor Crop ${ }^{1}$
}

\author{
Manejo de Plantas Daninhas com Herbicidas Aplicados em Pré e Pós-Emergência na Cultura da \\ Mamoneira
}

\author{
COSTA, A.G.F. ${ }^{2}$, SOFIATTI, V. ${ }^{2}$, MACIEL, C.D.G. ${ }^{3}$, LIRA, A.J.S. ${ }^{2}$, CORDEIRO JR., A.F. ${ }^{2}$, and \\ SILVA, R.L.M. ${ }^{4}$
}

\begin{abstract}
The aim of this work was to evaluate the weed management with herbicides applied in pre and postemergence on castor crop. The treatments were constituted by management systems using herbicides in pre (PRE) and postemergence (POS): 1) S-metolachlor at $576 \mathrm{~g} \mathrm{ha}^{-1}$ (PRE 1) and chlorimuron-methyl at $15 \mathrm{~g} \mathrm{ha}^{-1}$ (POS 1); 2) PRE 1 + clomazone at $650 \mathrm{~g} \mathrm{ha}^{-1}$ (PRE 2) and POS 1; 3) PRE 1, POS 1 and halosulfuron-methyl at $112.5 \mathrm{~g} \mathrm{ha}^{-1}$ (POS 2); 4) PRE 1, POS 1 and ethoxysulfuron at $60 \mathrm{~g} \mathrm{ha}^{-1}$ (POS 3); 5) PRE 1, POS 1 and ethoxysulfuron at $120 \mathrm{~g} \mathrm{ha}^{-1}$ (POS 4); 6) PRE 1 + PRE 2, POS 1 and POS 2; 7) PRE 1 + PRE 2, POS 1 and POS 3; 8) PRE 1 + PRE 2, POS 1 and POS 4; 9) hand-hoeing control and 10) non-weeded control. The experimental design was randomized blocks with four replications. The association of the herbicides in PRE combined to sequence applications of chlorimuron-ethyl and halosulfuron-methyl or ethoxysulfuron in POS resulted in the highest control levels of Richardia scabra and Cyperus ferax. Mild phytointoxication symptoms to the crop were more persistent with ethoxysulfuron at $120 \mathrm{~g} \mathrm{ha}^{-1}$. The acceptable control of the weed species and similar yield to the hand-hoeing control permitted to conclude that S-metolachlor + clomazone PRE, followed by chlorimuron-ethyl and halosulfuron-methyl POS proved to be more adequate as a weed management strategy on castor crop.
\end{abstract}

Keywords: Ricinus communis, Cyperus ferax, Richardia scabra, efficiency.

\begin{abstract}
RESUMO - Objetivou-se com este trabalho avaliar o manejo de plantas daninhas com herbicidas aplicados em pré e pós-emergência na cultura da mamoneira. Os tratamentos foram constituídos por sistemas de manejo utilizando-se herbicidas em pré (PRE) e pós-emergência (POS): 1) S-metolachlor a $576 \mathrm{~g} \mathrm{ha}^{-1}$ (PRE 1) e chlorimuron-methyl a $15 \mathrm{~g} \mathrm{ha}^{-1}$ (POS 1); 2) PRE 1 + clomazone a $650 \mathrm{~g} \mathrm{ha}^{-1}$ (PRE 2) e POS 1; 3) PRE 1, POS 1 e halosulfuron-methyl a 112,5 $\mathrm{g} \mathrm{ha}^{-1}$ (POS 2); 4) PRE 1, POS 1 e ethoxysulfuron a $60 \mathrm{~g} \mathrm{ha}^{-1}$ (POS 3); 5) PRE 1, POS 1 e ethoxysulfuron a $120 \mathrm{~g} \mathrm{ha}^{-1}$ (POS 4); 6) PRE 1 + PRE 2, POS 1 e POS 2; 7) PRE 1 + PRE 2, POS 1 e POS 3; 8) PRE 1 + PRE 2, POS 1 e POS 4; 9) testemunha capinada; e 10) testemunha sem capina. O delineamento experimental foi o de blocos casualizados com quatro repetições. A associação dos herbicidas em PRE combinada às aplicações sequenciais de chlorimuron-ethyl e halosulfuron-methyl ou ethoxysulfuron em POS resultaram nos maiores niveis de controle de Richardia scabra e Cyperus ferax. Sintomas leves de intoxicação à cultura foram mais persistentes com ethoxysulfuron a $120 \mathrm{~g} \mathrm{ha}^{-1}$. O controle aceitável das espécies infestantes e a produtividade semelhante à obtida com a testemunha capinada permitiram concluir que S-metolachlor + clomazone em PRE, seguido de chlorimuron-ethyl e halosulfuron-methyl em POS, se mostrou mais adequado como estratégia de manejo de plantas daninhas na cultura da mamoneira.
\end{abstract}

Palavras-chave: Ricinus communis, Cyperus ferax, Richardia scabra, eficiência.

1 Recebido para publicação em 2.6.2015 e aprovado em 26.6.2015.

2 Embrapa Algodão, Campina Grande-PB. Brasil, <augusto.costa@embrapa.br>; ${ }^{3}$ Universidade Estadual do Centro-Oeste. Guarapuava-PR. Brasil; ${ }^{4}$ Universidade Estadual da Paraíba, UEPB - Campina Grande-PB, Brasil. 


\section{INTRODUCTION}

Brazil is the world's fourth largest producer of castor (FAO, 2015), with average production, cultivated area and productivity of 66 thousand tons, 139,000 ha and $419 \mathrm{~kg} \mathrm{ha}^{-1}$, respectively, in the last five harvests (Conab, 2015). Considering that castor can produce more than $4,000 \mathrm{~kg}$ of seeds ha-1 (Soratto et al., 2011), Brazilian productivity is considered extremely low, requiring the improvement of its production systems for greater profitability and crops expansion.

In this context, the occurrence of weeds is among the main factors affecting the productivity of castor and can be reduced by more than $80 \%$ in areas of high infestation. The $\mathrm{C}_{3}$ photosynthetic metabolism and the slow initial growth of the culture, as well as the low sowing densities and wide spacing traditionally used, are among the main causes of low competitiveness of castor plant (Azevedo et al., 2006).

To prevent weed interference in castor culture, mechanical control with cultivator, hoe or mowing cutter have been primarily used, which results in low efficiency and high dependence on labor, which is increasingly scarce and expensive. In addition, smaller spacing used with new cultivars or low sized hybrids have hindered this method of control. Therefore, despite the use of herbicides in the culture of castor not being more widespread among producers yet, it is the most practical and economical control method (Maciel et al., 2008), becoming increasingly necessary. In this sense, despite the existing information on the technical feasibility of application of herbicides for the cultivation of castor (Costa et al., 2014), there are not selective products registered in Ministério da Agricultura, Pecuária e Abastecimento (MAPA; Ministry of Agriculture, Livestock and Supply) (Brasil, 2015).

In studies carried out, it has been found that there are herbicides that are selective to castor, with a predominant effect on monocotyledons of the Poaceae family, such as pendimethalin, trifluralin and clomazone in preemergence, despite affecting some eudicotyledon species. Another option to control grass species are the ACCase
(Acetyl-CoA carboxylase (ACC)) inhibitor herbicides applied postemergence, such as fluazifop-p-butil, sethoxydim, haloxyfop-methyl, quizalofop-p-ethyl, clethodim, clethodim + fenoxaprop-p-ethyl, propaquizafop and butroxydim (Maciel et al., 2007, 2008, 2012; Silva et al., 2012; Grichar et al., 2012; Medeiros et al., 2013). Thus, the control of eudicotyledons from the culture implementation would be more difficult for chemical control, for only chlorimuron-ethyl has proven to be selective for castor and has good control of species of this class (Maciel, 2006; Sofiatti et al., 2012).

The possibility of applying herbicides in preemergence, alone or in combination, followed by one or more postemergence applications, can be a strategy to enhance the control of eudicotyledons plants. Sofiatti et al. (2012) have found greater control of Walteria indica in the culture of castor when using trifluralin, clomazone, pendimethalin or clomazone + trifluralin followed by chlorimuron-ethyl, mentioning that more efficient programs to weed management should be developed for the cultivation of castor. In this context, other studies have indicated the possibility of alternatives of herbicides with a potential for use in the culture, such as halosulfuron-methyl (Silva et al., 2010) and S-metolachlor (Monteiro et al., 2013). The latter has an effect on monocotyledons and some eudicotyledon weeds. Halosulfuron-methyl can be used for controlling sedges, especially purple nutsedge (Cyperus rotundus), and contribute to the control of some eudicotyledon species (Trader et al., 2008; Walters \& Young, 2010; Brasil, 2015).

Therefore, further studies aimed at possible combinations or associations of herbicides are needed for evolution of knowledge on the management of weeds in the crop of castor, making it possible to obtain information that contributes to the improvement of its production systems. Thus, the aim of this study was to evaluate weed management with the combination of herbicides applied in pre and postemergence in the culture of castor.

\section{MATERIALS AND METHODS}

The work was conducted in a experimental area located at coordinates $07^{\circ} 09^{\prime} 67^{\prime \prime} \mathrm{S}$ and 
35'53'04" W, with an average altitude of 634 $\mathrm{m}$, from June to November 2012. The climate, according to Köppen, is type As', characterized as tropical with autumn and winter rains. The average annual temperature is between $22^{\circ} \mathrm{C}$ and $26{ }^{\circ} \mathrm{C}$, and the average annual rainfall is $990 \mathrm{~mm}$.

The soil of the experimental area was classified as solodic psamitic regolitic entisol (Embrapa, 1999), being made up of $84.8 \%$ sand, $9.41 \%$ silt and $5.79 \%$ clay. The chemical characteristics sampled before installing the test for the layer from 0 to $20 \mathrm{~cm}$ were: $\mathrm{pH}$ in water $=5.4 ; \mathrm{Ca}^{+2}=23.4 \mathrm{mmol}_{\mathrm{c}} \mathrm{dm}^{-3} ; \mathrm{Mg}=$ $6.3 \mathrm{mmol}_{\mathrm{c}} \mathrm{dm}^{-3} ; \mathrm{H}^{+}+\mathrm{Al}=22.3 \mathrm{mmol}_{\mathrm{c}} \mathrm{dm}^{-3} ; \mathrm{CEC}$ (cation-exchange capacity) $=53.9 \mathrm{mmol}_{\mathrm{c}} \mathrm{dm}^{-3}$; $\mathrm{V} \%=58.7 ; \mathrm{Al}^{+3}=0.5 \mathrm{mmol}_{\mathrm{c}} \mathrm{dm}^{-3} ; \mathrm{P}=$ $45.6 \mathrm{mg} \mathrm{dm}^{-3} ; \mathrm{K}^{+}=1.5 \mathrm{mmol}_{\mathrm{c}} \mathrm{dm}^{-3}$; and $\mathrm{MO}=9.3 \mathrm{~g} \mathrm{~kg}^{-1}$.

Castor seeding (cultivar BRS Energia) was performed on $6 / 2012$ with a sowing machine pulled by a tractor, using spacing of $0.9 \mathrm{~m}$ between rows and density of 2.5 seeds $\mathrm{m}^{-1}$. The base fertilization was done during sowing with $300 \mathrm{~kg}$ of monoammonium phosphate ha${ }^{1}$, and there were two applications for coverage, with $100 \mathrm{~kg} \mathrm{ha}^{-1}$ of urea, at 30 and 60 days after emergence (DAE) of the culture.

The treatments consisted of management systems using associated or combined herbicides and doses in pre(PRE) and postemergence (POS): 1) S-metolachlor at $576 \mathrm{~g} \mathrm{ha}^{-1}$ (PRE 1) and chlorimuron-methyl at $15 \mathrm{~g} \mathrm{ha}^{-1}$ (POS 1); 2) PRE 1 + clomazone at $650 \mathrm{~g} \mathrm{ha}^{-1}$ (PRE 2) and POS 1; 3) PRE 1, POS 1 and halosulfuron-methyl at $112.5 \mathrm{~g} \mathrm{ha}^{-1}$ (POS 2); 4) PRE 1, POS 1 and ethoxysulfuron at $60 \mathrm{~g} \mathrm{ha}^{-1}$ (POS 3); 5) PRE 1, POS 1 and ethoxysulfuron at $120 \mathrm{~g} \mathrm{ha}^{-1}$ (POS 4); 6) PRE 1 + PRE 2, POS 1 and POS 2; 7) PRE 1 + PRE 2, POS 1 and POS 3; 8) PRE $1+$ PRE 2, POS 1 and POS 4; 9) hand-hoeing control and 10) nonweeded control. The experimental design was randomized blocks with four replications. The experimental units consisted of $6.0 \times 4.5 \mathrm{~m}$ $\left(27 \mathrm{~m}^{2}\right)$ plots. The application of herbicides in preemergence was done one day after seeding and in mixing, when using two active ingredients. Chlorimuron-ethyl was applied at $25 \mathrm{DAE}$ and halosulfuron-methyl and ethoxysulfuron at 32 DAE. Mineral oil (428 $\mathrm{g} \mathrm{L}^{-1}$ p. c.) was added at concentrations of
0.05 and $0.5 \%\left(\mathrm{v} \mathrm{v}^{-1}\right)$ to the application solutions of chlorimuron-ethyl and halosulfuron-methyl, respectively.

Castor plant presented between four and six true leaves at the time of application of the herbicides in postemergence when predominant infestation was of Richardia scabra with four to eight true leaves and Cyperus ferax in the pre-flowering stage. Applications were done with a $\mathrm{CO}_{2}$ pressurized backpack sprayer, equipped with a bar with spray nozzles of flat fan of expanded use (XR 11002VS), spaced $0.5 \mathrm{~m}$, at a pressure of $160 \mathrm{kPa}$ and spray solution consumption of $200 \mathrm{~L} \mathrm{ha}^{-1}$. The seven-day interval between the application of chlorimuron-ethyl and the other herbicides in postemergence was adopted in order to reduce the risk of poisoning plants in the crop. Throughout the experimental period, the control with weeding was kept free of infestation by manual weeding. The rainfall and the average, minimum and maximum temperatures occurring monthly in the experimental area are shown in Figure 1.

The intoxication visual assessments of castor plants and weed control were done at 7 , 15 and 23 days after the last application (DAA) in postemergence (halosulfuron-methyl and ethoxysulfuron). Ratings were assigned based on scales from European Weed Research Council (EWRC, 1964), wherein for phytointoxication one has 1: absence of symptoms; 2: very mild symptom; 3: mild symptom; 4: moderate symptom; 5: average symptom; 6: almost strong symptom; 7: strong symptom; 8: very strong symptom; 9: plant death. For control, one has: 1: total plant death $(100 \%)$; 2: excellent (98.0 to $99.9 \%)$; 3: very good (95.0 to $97.9 \%$ ); 4: good to acceptable (90 to $94.9 \%)$; 5: moderate (82.0 to $89.9 \%)$; 6: weak (70.0 to $81.9 \%)$; 7 : bad (55.0 to $69.9 \%$ ); 8: very bad (30 to $54.9 \%$ ); and 9: none (0.0 to $29.9 \%)$.

At the end of the trial period (130 DAE), before the harvest, the stem diameter was evaluated, which was measured at ground level using a digital caliper; plant height, measured by the length from the soil surface to the start of insertion of the plants apical bud; yield components (number of racemes per plant, number of seeds per raceme and mass 


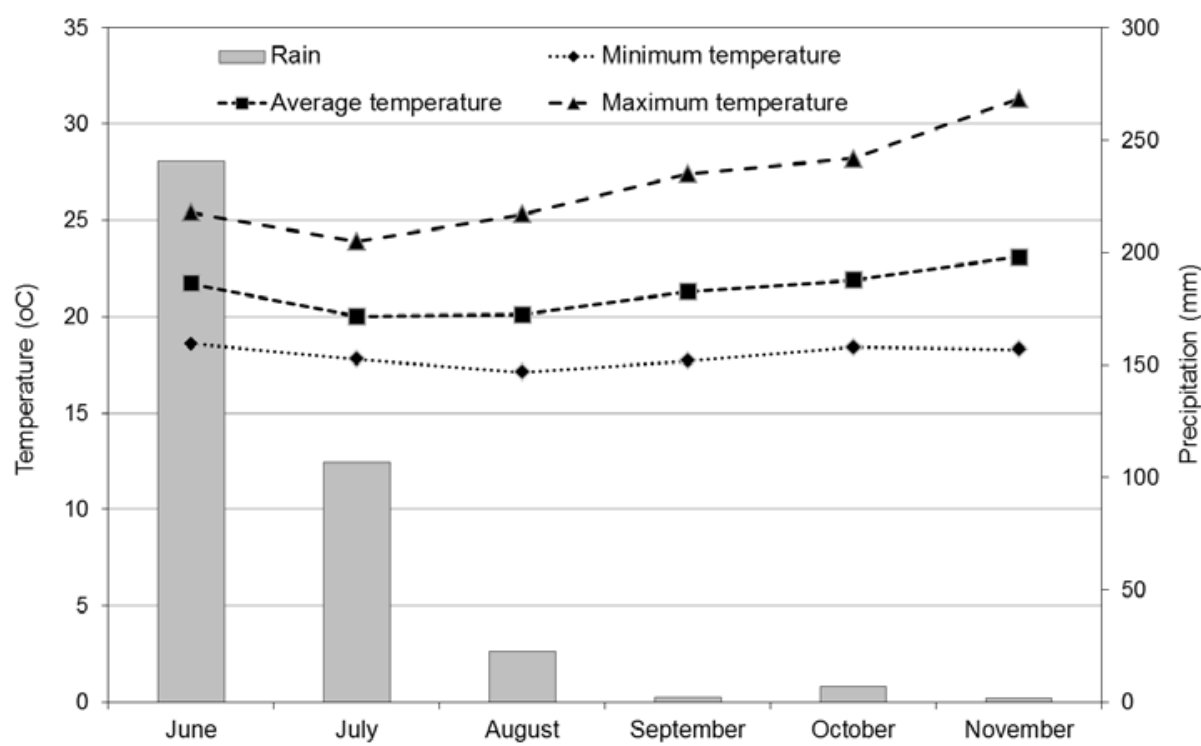

Data: Empresa Estadual de Pesquisa Agropecuária da Paraíba (Emepa).

Figure 1 - Rainfall (mm) and average, minimum and maximum temperatures in the months relative to the experimental period (June-November 2012).

of 100 seeds); productivity; and seed oil content. In all the characteristics were considered the two central rows of plants in each plot for evaluations or samplings, discounting $0.5 \mathrm{~m}$ of their ends. The oil content was determined nondestructively by means of a nuclear magnetic resonance spectrometer (RMN) H1 Oxford MQA 7005. The data were submitted to analysis of variance, and means were compared by t-test at $5 \%$ probability.

\section{RESULTS AND DISCUSSION}

For the weed $R$. scabra the management systems with a mixture in a tank of $\mathrm{S}$-metolachlor + clomazone in PRE, followed by the sequence application of chlorimuron-ethyl and ethoxysulfuron in POS, in both doses used, resulted in moderate levels of control at 7 DAA, whose values were intensified during the evaluations, reaching efficiency ratings corresponding to acceptable or very good in the last two assessments (Table 1). The management with S-metolachlor + clomazone in PRE followed by a sequence application of chlorimuron-ethyl and halosulfuron-methyl in POS has presented an acceptable control at 23 DAA. All other combinations of herbicides showed levels below 7 DAA, resulting only in efficiency levels considered weak to moderate in the last assessment. Therefore, the results demonstrated that the combination of herbicides S-metolachlor + clomazone in PRE and the use of ethoxysulfuron (60 or $120 \mathrm{~g} \mathrm{ha}^{-1}$ ) in sequence application to chlorimuron-ethyl in POS have favored getting better levels of control for R. scabra. Similarly, the good level of control was observed for the sequence handling with halosulfuron-methyl, from 15 DAA. Importantly, the association's dependence on herbicides in PRE and the sequence application in POS for an at least acceptable control of this species can be explained by the effects of these herbicides on eudicotyledons.

Clomazone and S-metolachlor, while having predominantly graminicidal action, have some efficacy on some eudicotyledons, being even recommended for the control of other species of the genus (Richardia brasiliensis), but in larger doses than those used in this study (Brasil, 2015). Therefore, the association of the herbicides in PRE may have favored the control of $R$. scabra compared to the isolated use of S-metolachlor. In a study conducted by Monquero et al. (2001), an 
unsatisfactory control of $R$. brasiliensis with $15 \mathrm{~g} \mathrm{ha}^{-1}$ of chlorimuron-ethyl at 14 DAA was found. In the present study, ethoxysulfuron and halosulfuron-methyl, because they belong to the same chemical group of chlorimuron-ethyl (sulfonylureas), may have presented some effect on $R$. scabra, supplementing the action of the previously applied herbicides. In this context, Trader et al. (2008) have found that clomazone + ethalfluralin in PRE, associated with the application of halosulfuron-methyl (PRE or POS), have resulted in minimal increase of $44 \%$ in the control of Amaranthus hybridus regarding the use of clomazone + ethalfluralin.

Regarding the species $C$. ferax (Table 1) at 15 DAA the control performed between moderate and good for the management systems with the mixture in tank of S-metolachlor + clomazone in PRE, followed by the second sequence application of ethoxysulfuron or halosulfuron-methyl in POS. At 23 DAA, S-metolachlor + clomazone, associated with the application in POS of chlorimuron-ethyl and halosulfuron-methyl or ethoxysulfuron (60 or $120 \mathrm{~g} \mathrm{ha}^{-1}$ ) in the sequence resulted in improved levels of control: between very good and excellent. The other treatments showed ratings closer to 4, corresponding to a good level of control. Similarly to what happened to control R. scabra, clomazone association to S-metolachlor and the sequence application of halosulfuron-methyl or ethoxysulfuron after chlorimuron-ethyl have increased the control of C. ferax. The greater control of this species due to the application of halosulfuron-methyl and ethoxysulfuron confirms the high efficacy of these herbicides on Cyperaceae (known as sedges) (Trader et al., 2008; Agostinetto et al., 2011; Khalik \& Matloob, 2012), plus ethoxysulfuron is also registered for control of C. ferax (Brasil, 2015).

Table 1 - Control of R. scabra and C. ferax at 7, 15 and 23 days after application (DAA) of the second sequence in postemergence (visual ratings scale of EWRC, 1964)

\begin{tabular}{|c|c|c|c|c|c|c|c|}
\hline \multirow{3}{*}{ Treatment } & \multirow{3}{*}{$\begin{array}{c}\text { Dose } \\
\left(\mathrm{g} \mathrm{ha}^{-1}\right)\end{array}$} & \multicolumn{6}{|c|}{ Control - EWRC (1964) ${ }^{4 /}$} \\
\hline & & \multicolumn{3}{|c|}{ Richardia scabra } & \multicolumn{3}{|c|}{ Cyperus ferax } \\
\hline & & $7 \mathrm{DAA}$ & $15 \mathrm{DAA}$ & $23 \mathrm{DAA}$ & $7 \mathrm{DAA}$ & 15 DAA & $23 \mathrm{DAA}$ \\
\hline $\begin{array}{l}\text { 1. S-metolachlor }{ }^{1 /} \\
\text { Chlorimuron-ethyl }{ }^{2 /}\end{array}$ & $\begin{array}{c}576 \\
15\end{array}$ & 6.3 & 5.8 & 5.5 & 6.5 & 5.8 & 3.8 \\
\hline $\begin{array}{l}\text { 2. S-metolachlor + clomazone }{ }^{\underline{1}} \\
\text { Chlorimuron-ethyl }^{2 /}\end{array}$ & $\begin{array}{c}576+650 \\
15\end{array}$ & 6.0 & 5.0 & 5.5 & 7.0 & 5.3 & 4.0 \\
\hline $\begin{array}{l}\text { 3. S-metolachlor }{ }^{\underline{1}{ }^{\prime}} \\
\text { Chlorimuron-ethyl }{ }^{2 /} \\
\text { Halosulfuron-methyl }^{\underline{3}}\end{array}$ & $\begin{array}{c}576 \\
15 \\
112.5\end{array}$ & 7.0 & 6.3 & 6.0 & 6.8 & 6.0 & 3.5 \\
\hline $\begin{array}{l}\text { 4. S-metolachlor }{ }^{1 /} \\
\text { Chlorimuron-ethyl }{ }^{2 /} \\
\text { Ethoxysulfuron }{ }^{-}{ }^{\prime}\end{array}$ & $\begin{array}{c}576 \\
15 \\
60\end{array}$ & 6.3 & 5.0 & 5.3 & 6.0 & 4.8 & 3.5 \\
\hline $\begin{array}{l}\text { 5. S-metolachlor }{ }^{1 /} \\
\text { Chlorimuron-ethyl }{ }^{2 /} \\
\text { Ethoxysulfuron }^{\frac{3}{}}\end{array}$ & $\begin{array}{c}576 \\
15 \\
120\end{array}$ & 6.8 & 4.3 & 4.8 & 5.3 & 4.5 & 3.8 \\
\hline $\begin{array}{l}\text { 6. S-metolachlor + clomazone } \mathrm{e}^{\underline{1}} \\
\text { Chlorimuron-ethyl } \mathrm{l}^{\underline{\prime} /} \\
\text { Halosulfuron-methyl }^{\underline{3}}\end{array}$ & $\begin{array}{c}576+650 \\
15 \\
112.5\end{array}$ & 6.0 & 5.5 & 4.8 & 6.3 & 4.5 & 3.0 \\
\hline $\begin{array}{l}\text { 7. S-metolachlor }+ \text { clomazone }^{\underline{1}} \\
\text { Chlorimuron-ethyl }{ }^{2 /} \\
\text { Ethoxysulfuron }^{\underline{3}}\end{array}$ & $\begin{array}{c}576+650 \\
15 \\
60\end{array}$ & 5.5 & 4.0 & 4.3 & 6.3 & 4.3 & 2.3 \\
\hline $\begin{array}{l}\text { 8. S-metolachlor + clomazone }{ }^{\underline{1}} \\
\text { Chlorimuron-ethyl } \mathrm{l}^{2 /} \\
\text { Ethoxysulfuron }^{\underline{3}}\end{array}$ & $\begin{array}{c}576+650 \\
15 \\
120\end{array}$ & 5.0 & 4.0 & 3.5 & 6.5 & 4.5 & 3.3 \\
\hline 9. Weeded control & --- & 9.0 & 9.0 & 9.0 & 9.0 & 9.0 & 9.0 \\
\hline 10. Control without hoeing & --- & 1.0 & 1.0 & 1.0 & 1.0 & 1.0 & 1.0 \\
\hline
\end{tabular}

1/ Single application in preemergence (PRE); ${ }^{2}$ first application in postemergence (POS); ${ }^{3 /}$ second application in POS; ${ }^{4 /} 1$ : total death of the plants; 2: excellent; 3: very good; 4: good to acceptable; 5: moderate; 6: weak; 7: bad; 8: very bad; 9: none. 
Considering the increasing control efficiency due to herbicides applied in PRE and POS used in this study, in a work on rice cultivation, the application of clomazone in PRE followed by clomazone + halosulfuron in initial POS has increased the control of Cyperus compressus and Sesbania exaltata when compared to the application of clomazone only, under the same application methods (Willingham et al., 2008).

Intoxication symptoms observed in castor plants were classified as very mild or mild in the assessments at 7 and 15 DAA of the sequence in POS. In these evaluations, larger average values of injuries (between 2.3 and 3.0) were caused mainly with ethoxysulfuron in the dose of $120 \mathrm{~g} \mathrm{ha}^{-1}$ (Table 2). At 23 DAA, this same management system with ethoxysulfuron at the highest dose has also resulted in an average plant intoxication considered very mild; however, for the other treatments there were no symptoms or the averages were very close to a low level of injury, indicating visual recovery of the crop for the management systems with the studied herbicides.

For clomazone applied in PRE, although some early symptom of toxicity may be found for castor, the plants were subsequently recovered and the product is considered to be selective in doses of up to $750 \mathrm{~g} \mathrm{ha}^{-1}$, as well as chlorimuron-ethyl in a dose of $15 \mathrm{~g} \mathrm{ha}^{-1}$ (Maciel et al., 2007; Sofiatti et al., 2012). For halosulfuron-methyl, Silva et al. (2010) have also found very mild symptoms of intoxication at 7 DAA with $112.5 \mathrm{~g} \mathrm{ha}^{-1}$, and symptoms

Table 2 - Poisoning of the plants at 7, 15 and 23 days after application (DAA) of the second sequence in postemergence (visual ratings scale of EWRC, 1964), stem height $(\mathrm{m})$ and diameter $(\mathrm{mm})$ of the castor in preharvest, due to weeds management systems with herbicides in pre and postemergence

\begin{tabular}{|c|c|c|c|c|c|c|}
\hline \multirow[t]{2}{*}{ Treatment } & \multirow{2}{*}{$\begin{array}{l}\text { Dose } \\
\left(\mathrm{g} \mathrm{ha}^{-1}\right)\end{array}$} & \multicolumn{3}{|c|}{$\begin{array}{c}\text { Intoxication } \\
\text { EWRC (1964) }\end{array}$} & \multirow{2}{*}{$\begin{array}{l}\text { Height } \\
\text { (m) }\end{array}$} & \multirow{2}{*}{$\begin{array}{l}\text { Diameter } \\
(\mathrm{mm})\end{array}$} \\
\hline & & 7 DAA & 15 DAA & $23 \mathrm{DAA}$ & & \\
\hline $\begin{array}{l}\text { 1. S-metolachlor }{ }^{1 /} \\
\text { Chlorimuron-ethyl }^{\underline{2} /}\end{array}$ & $\begin{array}{c}576 \\
15\end{array}$ & 1.8 & 1.8 & 1.0 & 0.85 & 8.43 \\
\hline $\begin{array}{l}\text { 2. S-metolachlor + clomazone } \mathrm{e}^{\underline{1}} \\
{\text { Chlorimuron-ethyl }{ }^{2 /}}^{\prime \prime} \\
\end{array}$ & $\begin{array}{c}576+650 \\
15\end{array}$ & 1.8 & 1.5 & 1.0 & 0.85 & 8.48 \\
\hline $\begin{array}{l}\text { 3. S-metolachlor }{ }^{1 /} \\
\text { Chlorimuron-ethyl }^{2 /} \\
\text { Halosulfuron-methyl }^{\underline{\underline{ }}}\end{array}$ & $\begin{array}{c}576 \\
15 \\
112.5 \\
\end{array}$ & 1.5 & 1.3 & 1.3 & 0.98 & 9.17 \\
\hline $\begin{array}{l}\text { 4. S-metolachlor }{ }^{1 /} \\
\text { Chlorimuron-ethyl }{ }^{2 /} \\
\text { Ethoxysulfuron }^{\frac{3}{}} \\
\end{array}$ & $\begin{array}{c}576 \\
15 \\
60 \\
\end{array}$ & 2.0 & 1.5 & 1.3 & 0.87 & 8.46 \\
\hline $\begin{array}{l}\text { 5. S-metolachlor }{ }^{1 /} \\
\text { Chlorimuron-ethyl } \mathrm{l}^{2 /} \\
\text { Ethoxysulfuron }^{3 /}\end{array}$ & $\begin{array}{c}576 \\
15 \\
120 \\
\end{array}$ & 2.8 & 2.3 & 1.3 & 0.76 & 8.45 \\
\hline $\begin{array}{l}\text { 6. S-metolachlor + clomazone } \mathrm{e}^{\underline{1} /} \\
\text { Chlorimuron-ethyl }{ }^{2 /} \\
\text { Halosulfuron-methyl }^{3 /}\end{array}$ & $\begin{array}{c}576+650 \\
15 \\
112.5 \\
\end{array}$ & 1.5 & 1.5 & 1.0 & 0.98 & 8.83 \\
\hline $\begin{array}{l}\text { 7. S-metolachlor + clomazone } \mathrm{e}^{\frac{1}{}} \\
\text { Chlorimuron-ethyl } \mathrm{l}^{2 /} \\
\text { Ethoxysulfuron }^{\frac{3}{}}\end{array}$ & $\begin{array}{c}576+650 \\
15 \\
60\end{array}$ & 2.3 & 1.8 & 1.3 & 0.91 & 9.06 \\
\hline $\begin{array}{l}\text { 8. S-metolachlor + clomazone } \mathrm{e}^{\underline{1} /} \\
\text { Chlorimuron-ethyl } \mathrm{l}^{2 /} \\
\text { Ethoxysulfuron }^{\frac{3}{}}\end{array}$ & $\begin{array}{c}576+650 \\
15 \\
120\end{array}$ & 3.0 & 2.5 & 1.8 & 0.79 & 13.18 \\
\hline 9. Weeded control & $\begin{array}{ll}-- \\
\end{array}$ & 1.0 & 1.0 & 1.0 & 0.97 & 8.07 \\
\hline 10. Control without hoeing & $\begin{array}{c}-- \\
---\end{array}$ & 1.0 & 1.0 & 1.0 & 1.04 & 10.16 \\
\hline $\mathrm{F}$ & & - & - & - & $1.89^{\mathrm{ns}}$ & $0.83^{\text {ns }}$ \\
\hline CV $(\%)$ & & -- & -- & --- & 14.81 & 35.95 \\
\hline
\end{tabular}

${ }^{1 /}$ Single application in preemergence (PRE); ${ }^{\prime} /$ first application in postemergence (POS); ${ }^{3 /}$ second application in POS; ${ }^{4} / 1$ : absence of symptoms; 2: very mild symptom; 3: mild symptom; 4: moderate symptom; 5: average symptom; 6: almost strong symptom; 7: strong symptom; 8: very strong symptom; 9: plant death. Values followed by the same letter in the same column do not differ by t-test (p $\leq 0.05$ ). * significant ( $\mathrm{p} \leq 0.05)$; ${ }^{\mathrm{NS}}$ non significant. 
disappeared at 14 DAA, resulting in no reduction in the growth of castor. Regarding ethoxysulfuron, Costa et al. (2012) have verified a reduction in growth with $150 \mathrm{~g} \mathrm{ha}^{-1}$; however, with the dose of $60 \mathrm{~g} \mathrm{ha}^{-1}$ the symptoms of plants poisoning were moderate $(18 \%)$ at 25 DAA, without interfering with stem diameter and plant height. Therefore, previous results obtained with ethoxysulfuron have indicated that this herbicide can cause injuries to the crop, especially in higher doses, as verified by visual intoxication ratings assigned to plants in this study when using $120 \mathrm{~g} \mathrm{ha}^{-1}$. However, with respect to growth characteristics (plants stem height and diameter) evaluated at the time of harvesting (at $130 \mathrm{DAE}$ ) also shown in Table 2, it was not possible to confirm differences among treatments.
For the crop yield components, there was a higher number of racemes for the nonweeded control in relation to the weeded control, indicating that the interference of weed community has reduced this trait by 49\% (Table 3). All treatments with chemical management with herbicide systems applied in PRE and POS have resulted in increased racemes number compared to the control without weeding, and it was not possible to see differences among them. However, herbicide treatments have shown a number of racemes that was lower than in the weeded control, except only in the two situations in which both herbicides were used in PRE, followed by sequence applications of chlorimuron-ethyl and ethoxysulfuron in POS.

For number of seeds per raceme, weight of 100 seeds and oil content, it was not

Table 3 - Number of racemes per plant, number of seeds per raceme, weight of 100 seeds (g), grain yield (kg ha ${ }^{-1}$ ) and oil content in seeds (\%) of castor, due to the weed management systems with herbicides in pre and postemergence

\begin{tabular}{|c|c|c|c|c|c|c|}
\hline Treatment & $\begin{array}{l}\text { Dose } \\
\left(\mathrm{g} \mathrm{ha}^{-1}\right)\end{array}$ & Racemes/plant & Seeds/raceme & $\begin{array}{c}\text { Mass of one } \\
\text { hundred seeds } \\
\text { (g) }\end{array}$ & $\begin{array}{c}\text { Yield } \\
\left(\mathrm{kg} \mathrm{ha}^{-1}\right)\end{array}$ & $\begin{array}{c}\text { Oil content } \\
\text { (\%) }\end{array}$ \\
\hline $\begin{array}{l}\text { 1. S-metolachlor }{ }^{1 /} \\
\text { Chlorimuron-ethyl }{ }^{2 /}\end{array}$ & $\begin{array}{c}576 \\
15\end{array}$ & $2.61 \mathrm{~b}$ & 121.96 & 55.40 & $754.64 \mathrm{ab}$ & 44.78 \\
\hline $\begin{array}{l}\text { 2. S-metolachlor + clomazone }{ }^{\underline{1} /} \\
\text { Chlorimuron-ethyl }{ }^{2 /}\end{array}$ & $\begin{array}{c}576+650 \\
15\end{array}$ & $2.71 \mathrm{~b}$ & 107.60 & 54.46 & 850.94 bc & 46.08 \\
\hline $\begin{array}{l}\text { 3. S-metolachlor }{ }^{1 /} \\
\text { Chlorimuron-ethyl } l^{2 /} \\
\text { Halosulfuron-methyl }{ }^{3 /} \\
\end{array}$ & $\begin{array}{c}576 \\
15 \\
112.5 \\
\end{array}$ & $2.66 \mathrm{~b}$ & 103.79 & 55.99 & $1045.81 \mathrm{c}$ & 44.28 \\
\hline $\begin{array}{l}\text { 4. S-metolachlor }{ }^{1 /} \\
\text { Chlorimuron-ethyl }{ }^{2 /} \\
\text { Ethoxysulfuron }{ }^{3 /}\end{array}$ & $\begin{array}{c}576 \\
15 \\
60 \\
\end{array}$ & $2.76 \mathrm{~b}$ & 100.54 & 55.10 & 856.78 bc & 45.18 \\
\hline $\begin{array}{l}\text { 5. S-metolachlor }{ }^{1 /} \\
\text { Chlorimuron-ethyl } l^{2 /} \\
\text { Ethoxysulfuron }^{3 /}\end{array}$ & $\begin{array}{c}576 \\
15 \\
120\end{array}$ & $2.64 \mathrm{~b}$ & $95.02 \mathrm{a}$ & 54.91 & 871.74 bc & 44.20 \\
\hline $\begin{array}{l}\text { 6. S-metolachlor + clomazone } \mathrm{e}^{\underline{\underline{1}}} \\
\text { Chlorimuron-ethyl } \mathrm{l}^{2 /} \\
\text { Halosulfuron-methyl }{ }^{\frac{3 /}{}}\end{array}$ & $\begin{array}{c}576+650 \\
15 \\
112.5\end{array}$ & $2.67 \mathrm{~b}$ & 133.75 & 55.28 & $1106.29 \mathrm{~cd}$ & 44.88 \\
\hline $\begin{array}{l}\text { 7. S-metolachlor + clomazone } \mathrm{e}^{\underline{1}} \\
\text { Chlorimuron-ethyl } \mathrm{l}^{2 /} \\
\text { Ethoxysulfuron }^{\frac{3}{}}{ }^{\prime}\end{array}$ & $\begin{array}{c}576+650 \\
15 \\
60\end{array}$ & $2.93 \mathrm{bc}$ & 89.07 & 54.95 & $1067.49 \mathrm{c}$ & 45.60 \\
\hline $\begin{array}{l}\text { 8. S-metolachlor + clomazone }{ }^{1 /} \\
\text { Chlorimuron-ethyl }{ }^{2 /} \\
\text { Ethoxysulfuron }^{3 /}\end{array}$ & $\begin{array}{c}576+650 \\
15 \\
120 \\
\end{array}$ & $3.02 \mathrm{bc}$ & 121.38 & 56.11 & 903.60 bc & 44.85 \\
\hline 9. Weeded control & --- & $1.84 \mathrm{a}$ & 92.25 & 56.21 & 544.39 a & 45.90 \\
\hline 10. Control without hoeing & --- & $3.62 \mathrm{c}$ & 113.32 & 55.05 & $1357.91 \mathrm{~d}$ & 44.45 \\
\hline $\mathrm{F}$ & & $3.21^{*}$ & $0.85^{\mathrm{ns}}$ & $0.44^{\mathrm{ns}}$ & $5.13^{*}$ & $1.17^{\mathrm{ns}}$ \\
\hline $\mathrm{CV}(\%)$ & & 17.84 & 29.38 & 3.17 & 20.90 & 2.71 \\
\hline LSD (least significant difference) & & 0.71 & --- & --- & 283.81 & --- \\
\hline
\end{tabular}

1/ Single application in preemergence (PRE); ${ }^{2}$ first application in postemergence (POS); ${ }^{3}$ second application in POS. Values followed by the same letter in the same column do not differ by t-test ( $\mathrm{p} \leq 0.05)$. * significant $(\mathrm{p} \leq 0.05)$; ${ }^{\mathrm{Ns}}$ non significant. 
possible to confirm differences among the treatments (Table 3). The non-interference of the herbicides used in oil content is relevant, since it is a product of greater commercial interest produced from the cultivation of castor.

The highest grain yield was observed for the weeded control $\left(1357.9 \mathrm{~kg} \mathrm{~h}^{-1}\right)$, which did not differ significantly from the management system with the mixture in a tank of S-metolachlor + clomazone in PRE, followed by sequence application of chlorimuron-ethyl and halosulfuron-methyl in POS (1106.3 $\mathrm{kg} \mathrm{h}^{-1}$ ) (Table 3). Aside from management with S-metolachlor applied in PRE followed by chlorimuron-ethyl in POS, other chemical management systems had productivity values that were significantly higher than in the control condition without weeding, most likely due to the results observed for the control of weeds (Table 1). In an area infested with Waltheria indica and Cenchrus echinatus, Sofiatti et al. (2012) - when assessing the effect of applications of clomazone, clomazone + trifluralin, pendimethalin and trifluralin in PRE, followed or not by chlorimuron-ethyl in POS - have found that the productivity was similar to the weeded control only when combining the options in PRE and POS, due to the best efficacy on weeds. In other studies was found the possibility of use of chlorimuron-ethyl (Maciel, 2006), clomazone (Maciel et al., 2007), halosulfuron-methyl (Silva et al., 2010; Costa et al., 2012) and S-metolachlor (Monteiro et al., 2013) in the culture of castor.

Although management systems with $\mathrm{S}$-metolachlor + clomazone in PRE, combined with chlorimuron-ethyl and the sequence application of ethoxysulfuron or halosulfuronmethyl, have presented the best levels of control of the weed species evaluated, only the one containing halosulfuron-methyl has resulted in productivity similar to the one in the weeded control. This fact can be explained by possible deleterious effects of ethoxysulfuron on the crop, as the ratings of visual intoxication, although low, were higher for this herbicide. Thus, new research focused on the selectivity of herbicides to castor should also be developed to assess in greater depth the technical feasibility of ethoxysulfuron.
Therefore, based on the results obtained in this study, particularly the ones for the control of weeds and productivity, it was possible to infer that the mixture in a tank of S-metolachlor + clomazone in preemergence, combined with the sequence application of chlorimuron-ethyl and halosulfuron methyl in postemergence, was more suitable as a management strategy of weeds in the castor crop.

\section{ACKNOWLEDGEMENTS}

The study reported in this paper was supported by Embrapa (Empresa Brasileira de Pesquisa Agropecuária [Brazilian Agricultural Research Corporation], funded by the Ministry of Agriculture, Livestock and Food Supply. The authors also thank CNPq [Conselho Nacional de Desenvolvimento Científico e Tecnológico (National Counsel of Technological and Scientific Development)] by the scholarship provided for the last author.

\section{LITERATURE CITED}

AGOSTINETTO, D. et al. Resistência de Cyperus difformis L. ao herbicida pyrazosulfuron-ethyl e alternativas de controle. Semina: Ci. Agr., v. 32, n. 3, p. 839-848, 2011.

AZEVEDO, D. M. P. et al. Período crítico de competição entre mamoneira e plantas daninhas. R. Bras. Oleag. Fibr., v. 10, n. 1, p. 1017-1024, 2006.

BRASIL. Ministério da Agricultura, Pecuária e Abastecimento. Agrofit. Disponível em: <http:// extranet.agricultura.gov.br/agrofit_cons/ principal_agrofit_cons>. Acesso em: 15 maio 2015.

COMPANHIA NACIONAL DE ABASTECIMENTO CONAB. Mamona série histórica. Disponível em: <http:// www.conab.gov.br>. Acesso em: 15 maio 2015.

COSTA, A. G. F. et al. Seletividade de herbicidas pósemergentes à mamoneira para o controle de ciperáceas. In: CONGRESSO BRASILEIRO DE MAMONA, 5.; SIMPÓSIO INTERNACIONAL DE OLEAGINOSAS E ENERGÉTICAS, 2., 2012, Guarapari. Anais... Guarapari: Embrapa Algodão, 2012. CD ROM.

COSTA, A. G. F. et al. Weed management strategies for castor bean crops. Acta Sci. Agron., v. 36, n. 2, p. 135-145, 2014.

\section{EMPRESA BRASILEIRA DE PESQUISA}

AGROPECUÁRIA - EMBRAPA. Centro Nacional de Pesquisa de Solos. Sistema brasileiro de classificação de solos. Brasília: Produção de Informação, 1999. 412 p. 
EUROPEAN WEED RESEARCH COUNCIL - EWRC. Report of the 3th and 4th meetings of EWRC - Committee of methods in weed research. Weed Res., v. 4, n. 1, p. 88, 1964.

FAO. Faostat. Disponível em: <http://faostat.fao.org/>. Acesso em: 15 de maio de 2015.

GRICHAR, W. J. et al. Castor (Ricinus communis L.) tolerance to postemergence herbicides and weed control efficacy. Inter. J. Agron., v. 2012, p. 1-5, 2012.

KHALIQ, A.; MATLOOB, A. Germination and growth response of rice and weeds to herbicides under aerobic conditions. Inter. J. Agric. Biol., v. 14, n. 5, p. 776-780, 2012.

MACIEL, C. D. G. Manejo na cultura da mamona em sistema de semeadura direta. R. Plantio Direto, v. 25, n. 1, p. 38-40, 2006.

MACIEL, C. D. G. et al. Seletividade de herbicidas em cultivares de mamona. R. Bras. Oleag. Fibr., v. 11, n. 1, p. 47-54, 2007.

MACIEL, C. D. G. et al. Possibilidade de aplicação de misturas de herbicidas de ação total com jato dirigido em mamoneira de porte anão. Planta Daninha, v. 26, n. 2, p. 457-464, 2008.

MACIEL, C. D. G. et al. Desenvolvimento de cultivares de mamoneiras em relação à profundidade de semeadura e seletividade de herbicidas dinitroanilinas. Semina: Ci. Agr., v. 33, n. 1, p. 27-38, 2012.

MEDEIROS, K. A. A. et al. Tolerância de mamoneira ao herbicida trifluralin em solos com diferentes texturas. R. Bras. Eng. Agríc. Amb., v. 17, n. 12, p. 1333-1339, 2013.

MONQUERO, P. et al. Glyphosate em mistura com herbicidas alternativos para o manejo de plantas daninhas. Planta Daninha, v. 19, n. 3, p. 375-380, 2001.
MONTEIRO, D. R. et al. Seletividade do herbicida Smetolachlor para a cultura da mamoneira. In: BARROS, M. A. L. et al. ENCONTRO DA PRODUÇÃO CIENTÍFICA DA EMBRAPA ALGODÃO, 7., 2013, Campina Grande. Campina Grande: Embrapa Algodão, 2013. p. 17. (Documentos, 246).

SILVA, K. C. et al. Tolerância de mamoneira ao herbicida pendimethalin em solos com diferentes capacidades de adsorção. R. Bras. Eng. Agríc. Amb., v. 16, n. 12, p. 12981304, 2012.

SILVA, V. N. B. et al. Tolerância da cultura da mamoneira ao herbicida halosulfuron. In: CONGRESSO BRASILEIRO DE MAMONA, 4, SIMPÓSIO INTERNACIONAL DE OLEAGINOSAS E ENERGÉTICAS, 1., 2010, João Pessoa. Inclusão social e energia... Campina Grande: Embrapa Algodão, 2010. 1 CD ROM.

SOFIATTI, V. et al. Pre and postemergence herbicides for weed control in castor crop. Indust. Crops Prod., v. 37, n. 1, p. 235-237, 2012.

SORATTO, R. S. et al. Espaçamento e população de plantas de mamoneira de porte baixo para colheita mecanizada. Pesq. Agropec. Bras., v. 46, n. 3, p. 245-253, 2011.

TRADER, B. W. et al. Control of yellow nutsedge (Cyperus esculentus) and Smooth Pigweed (Amaranthus hybridus) in summer squash with halosulfuron. Weed Technol., v. 22, n. 6, p. 660-665, 2008.

WALTERS, S. A.; YOUNG, B. G. Effect of herbicide and cover crop on weed control in no-tillage jack-o-lantern pumpkin (Curcubita pepo L.) production. Crop Protec., v. 29, n. 1, p. 30-33, 2010.

WILLINGHAM, N. R. et al. Early postemergence clomazone tank mixes on coarse-textured soils in rice. Weed Technol., v. 22, n. 4, p. 565-570, 2008. 